\title{
Investigating the relationship between variation of greenhouse gases concentrations and humidex
}

\author{
Anies Ma'rufatin ${ }^{1,3,}{ }^{*}$, Haryoto Kusnoputranto ${ }^{2}$, and Kardono ${ }^{3}$ \\ ${ }^{1}$ School of Environmental Sciences, Universitas Indonesia, Jakarta, Indonesia \\ ${ }^{2}$ Department of Environmental Health, Faculty of Public Health, Universitas Indonesia, Jakarta, \\ Indonesia \\ ${ }^{3}$ Center of Technology for the Environment, Agency for the Assessment and Application of \\ Technology (BPPT), Jakarta, Indonesia
}

\begin{abstract}
The increasing greenhouse gases (GHGs) in the atmosphere contribute to increasing average temperature earth's surface. This research investigated relationship between variation of GHGs and human thermal comfort based on humidity index (humidex). This study applied humidex, an indices to assess the thermal comfort. The analysis was done by examining the observational data from two different monitoring stations in Serpong and Bogor. The result showed that the average $\mathrm{CO}_{2}$ concentration per month ranged between 422 and 453 ppm in Serpong, whereas in Bogor the average $\mathrm{CO}_{2}$ concentration per month was $413-426 \mathrm{ppm}$. The average $\mathrm{CH}_{4}$ concentration per month variation in Serpong was $2.05-2.65 \mathrm{ppm}$. While in Bogor, the average $\mathrm{CH}_{4}$ concentration per month variation ranged between 1.92 and $2.08 \mathrm{ppm}$. The difference of GHGs concentration in each location might be influenced by meteorological parameters and environmental characteristics. The comfort level according to humidex in Serpong was 30.5-41.5 whereas in Bogor was 29.4-38.5. The correlation between GHGs concentration and air temperature in urban areas in both stations showed a significant and strong but negative relationship. The relationship between GHGs concentration and humidex was indirectly indicated by the relationship of GHGs concentration on air temperature as indicator of humidex.
\end{abstract}

\section{Introduction}

Globally, the increasing of greenhouse gases (GHGs) concentration has been causing the rising temperatures in the atmosphere that is then affecting the decrease of human comfort [1]. The greenhouse gases (GHGs) are absorbing and emitting thermal radiation in the troposphere [2]. The atmospheric carbon is mainly in the form of carbon dioxide $\left(\mathrm{CO}_{2}\right)$ and methane $\left(\mathrm{CH}_{4}\right)$. Carbon dioxide is the most important greenhouse gas because it is produced abundantly and contributes $76.6 \%$ of human-caused climate impacts [3]. Methane

\footnotetext{
${ }^{*}$ Corresponding author: anies.marufatin@,bppt.go.id
} 
is the second most important greenhouse gas contributes $14 \%$ of greenhouse output [3]. Most of studies on measurement of GHGs in urban area focus on the variation concentration data such as in South Korea - Seoul [4], in Romania - Cluj-Napoca city, Turda city, Huedin town [5] and in India - Delhi [6]. This study focused on effect of variation GHGs concentration in urban area around Serpong and Bogor city, part of Greater Jakarta (Jabodetabek).

Study on thermal comfort in outdoor environment rarely found than indoor environment, whereas thermal comfort in outdoor environment related to climate change and increasing heat pressure in urban area [7]. Air quality monitoring in urban areas is an important issue in environmental research globally because urban area is the major source of air pollution [8]. Monitoring air quality indicators including GHGs in urban areas was an effort to realize low-carbon city development.

Study on outdoor human thermal comfort in urban area is aiming to improve the quality of life in the city [9]. There are several methods to improve the environmental sustainability of urban area to become more resilient to climate change effects. One of the methods is to assess the outdoor thermal comfort in urban area [1]. This study applied the Humidity Index (Humidex), one of the most frequently used indices to assess the thermal comfort [10]. Humidex is defined as the temperature of relatively dry air, which has the equivalent effect on human comfort as indicated by measured or forecasted temperature and humidity [11].

Urban area considered to be important agents in mitigating global climate change but at the same time the inhabitants and the infrastructures of the cities are exposed to the effects of climate change [10]. This study contributes in achieving relevant Sustainable Development Goals (SDGs), goal number 13: "Take urgent action to combat climate change and its impact". Assessing the thermal comfort related to the raising temperature as a climate change impact is considerable one of action to aim sustainable environment.

\section{Materials and methods}

\subsection{The study area}

In this study, the variation of greenhouse gases was investigated at two monitoring stations of urban areas of Greater Jakarta (Jabodetabek), Indonesia. Jabodetabek is the largest urban concentration of human activities in Indonesia that lays on three different provinces namely Capital City of Jakarta, Banten, and West Java. The population of Jabodetabek is estimated over 31 million people according to 2015 census with a total covered area of about 6,392 $\mathrm{km}^{2}$.

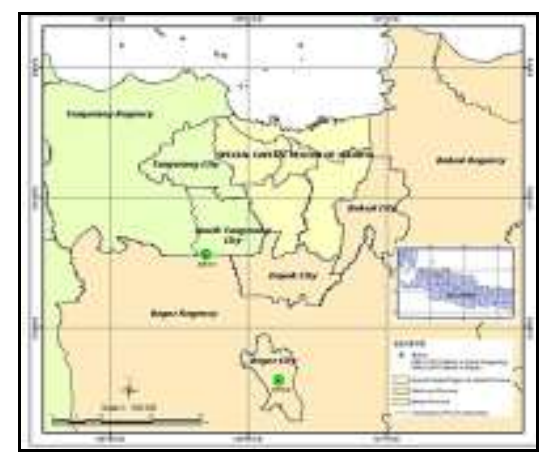

Fig. 1. Monitoring sites used in this study, Serpong and Bogor station. 
The first stations is located in Serpong as part of South Tangerang City $\left(-6^{\circ} 21^{\prime} 46.8^{\prime \prime} \mathrm{S}\right.$, $\left.106^{\circ} 40^{\prime} 12^{\prime \prime E}\right)$. South Tangerang City is an example of urban expansion phenomenon in peri-urban region [12]. South Tangerang City is one of the rapid urban expansions of residential areas. Station of Serpong was installed on the top of the Geostech Building, Research Centre for Science and Technology (Puspiptek) area. Puspiptek area is the national science and technology park that covers around 460 hectares. With its concept of eco-region the park is supported with more than $30 \%$ open green space [13].

The second stations is located in Bogor City $\left(-6^{\circ} 36^{\prime} 7.2^{\prime \prime} \mathrm{S}, 106^{\circ} 48^{\prime} 21.6^{\prime \prime} \mathrm{E}\right)$. Bogor is the $6^{\text {th }}$ largest city of Jabodetabek in distance about $60 \mathrm{~km}$ south of Jakarta and located 290 metres above sea level. The central part of Bogor is one of the most densely populated areas.

\subsection{Study method}

This study used quantitative approach to analyse GHGs concentration and thermal comfort by using comfort index, Humidex. The data used time series data from monitoring of GHGs concentration especially carbon dioxide $\left(\mathrm{CO}_{2}\right)$ and methane $\left(\mathrm{CH}_{4}\right)$; and meteorological parameters (temperature and relative humidity) in two monitoring sites (Serpong and Bogor station) from September 2016 to December 2017. To facilitate the calculation of relation between GHGs concentration and air temperature, the values of $\mathrm{CO}_{2}$ and $\mathrm{CH}_{4}$ concentration were converted to equivalent $\mathrm{CO}_{2}\left(\mathrm{CO}_{2} \mathrm{e}\right)$. The equivalent $\mathrm{CO}_{2}$ was obtained by summing up the value of $\mathrm{CO}_{2}$ concentration and the multiplication of $\mathrm{CH}_{4}$ concentration value and the Global Warming Potential of $\mathrm{CH}_{4}$ which was 21 .

Analysing the relationship of variation of GHGs concentration on air temperature was performed by correlation analysis. Furthermore, to analyse the effect of variation of GHG concentration to thermal comfort performed by simple regression analysis. A descriptive analysis on data that have been obtained was also conducted.

Table 1. Guide to thermal comfort for the different humidex ranges [14].

\begin{tabular}{|c|c|}
\hline Range of humidex & Degree of comfort \\
\hline $20-29$ & Comfort \\
\hline $30-39$ & Some discomfort \\
\hline $40-45$ & Discomfort \\
\hline Above 45 & Dangerous, heat stroke imminent \\
\hline
\end{tabular}

To assessing the thermal comfort based on Humidex was calculated by following formula:

$$
\begin{gathered}
H=T+[0.555 \times(e-10)] \\
e=6.112 \times 10^{(7.5 \times(T /(237.7+T)))} \times R H / 100
\end{gathered}
$$

where $H$ is Humidex, $T$ is air temperature $\left({ }^{\circ} \mathrm{C}\right), e$ is vapour pressure in millibars $(\mathrm{mb})$, and $R H$ is relative humidity (\%) [10]. Degrees of comfort were determined by range of humidex as seen in Table 1.

\section{Results and discussions}

Inter-monthly average of temperature at Serpong was in the range of $25.49-27.61^{\circ} \mathrm{C}$ while at Bogor was in the range $25.49-26.86^{\circ} \mathrm{C}$. Relative humidity $(\mathrm{RH})$ is an inverse function of 
temperature. Inter-monthly average of $\mathrm{RH}$ at Serpong was in the range of $65-81 \%$, while at Bogor was in the range of $62-75 \%$.

Fig 2 and Fig 3 shows the inter-monthly variation of $\mathrm{CO}_{2}$ and $\mathrm{CH}_{4}$ concentration in two sites. Patterns of $\mathrm{CH}_{4}$ concentration value both the highest value and the lowest value (Fig 3 ) has the same pattern of $\mathrm{CO}_{2}$ concentration (Fig 2). The values recorded at Serpong were higher than those at Bogor. Concentration of $\mathrm{CO}_{2}$ was in the range of 422-453 ppm at Serpong, while at Bogor was in the range of 413-426 ppm (Fig 2). The highest $\mathrm{CO}_{2}$ concentration at Serpong occurred on April 2017, while at Bogor the highest value occurred on May 2017. Variation of $\mathrm{CH}_{4}$ concentration values ranged between the lowest one of 2.05 ppm and the highest one of $2.65 \mathrm{ppm}$ at Serpong. While at Bogor the $\mathrm{CH}_{4}$ concentration values ranged between the lowest one of $1.92 \mathrm{ppm}$ and the highest one of $2.08 \mathrm{ppm}$.

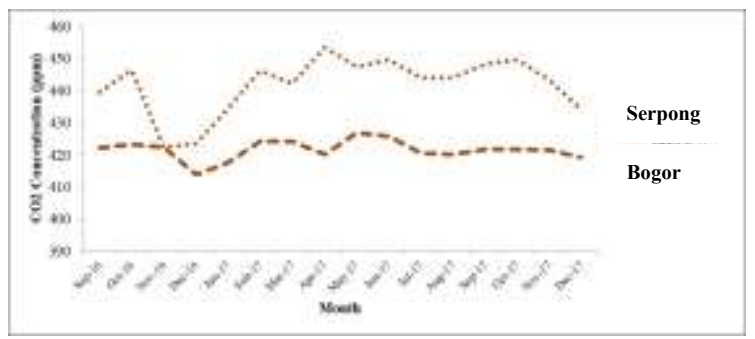

Fig 2. Inter-monthly pattern variation of $\mathrm{CO}_{2}$ concentration.

The result measurement in Serpong showed that air temperature and RH measurement higher than in Bogor. Consequently, it affects the comfort level in each location. The Humidex value in Serpong was 30,5-41,5 which means that its comfort level was some uncomfortable and uncomfortable. In Bogor, the humidex value was 29,4-38,5 in which the comfort level was comfortable and some uncomfortable.

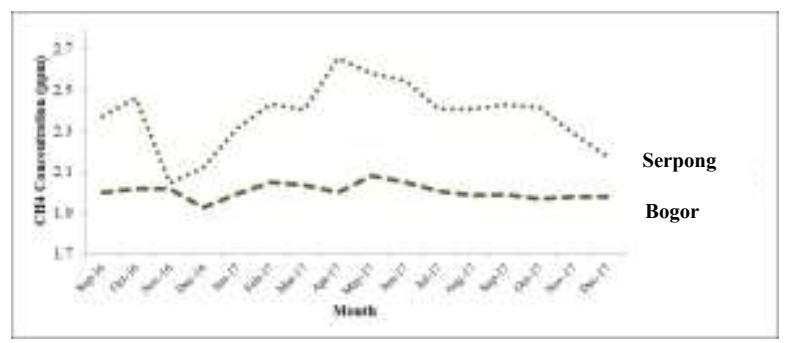

Fig 3. Inter-monthly pattern variation of $\mathrm{CH}_{4}$ concentration.

The Pearson correlation test in Serpong and Bogor in terms of the relation between $\mathrm{CO}_{2}$ and $\mathrm{CH}_{4}$ concentrations and air temperature resulted in the value of Sig. (2-tailed) $<\alpha$ (0.05). Thus, it can be concluded that GHGs concentration and air temperature have a significant relation. In Serpong, the correlation between air temperature and $\mathrm{CO}_{2}$ concentration resulted in the value of $\mathrm{r}=-0.805$, while the correlation between air temperature and $\mathrm{CH}_{4}$ concentration resulted in the value of $\mathrm{r}=-0.714$. Air temperature and GHGs concentration, $\mathrm{CO}_{2}$ and $\mathrm{CH}_{4}$, in Serpong had a strong relation. In Bogor, the correlation between air temperature and $\mathrm{CO}_{2}$ concentration resulted in the value of $\mathrm{r}=-$ 0.833, while the correlation between air temperature and $\mathrm{CH}_{4}$ concentration resulted in the value of $\mathrm{r}=-0.590$. It means that $\mathrm{CO}_{2}$ concentration and air temperature in Serpong had a 
negative, strong relation, while air temperature and $\mathrm{CH}_{4}$ concentration had a negative, adequate relation.

Based on the concentration of $\mathrm{CO}_{2}$ and $\mathrm{CH}_{4}$, the potential value of equivalent $\mathrm{CO}_{2}$ $\left(\mathrm{CO}_{2} \mathrm{e}\right)$ can be counted, so it facilitated an analysis of the relation of general GHGs concentration and air temperature. The simple linear regression analysis was conducted with dependent variable (Y), air temperature, and its independent variable, $\mathrm{CO}_{2} \mathrm{e}$. Fig 4 shows the relation between the value of $\mathrm{CO}_{2} \mathrm{e}$ and air temperature. In Serpong (Fig 4 (a)), the value of $\mathrm{R}^{2}=0.448$, means that $44.8 \%$ of variation models of air temperature in Serpong can be explained by $\mathrm{CO}_{2} \mathrm{e}$ concentration and the rest, $55.2 \%$, is affected by other factors. Fig 4 (b) shows the result of observation data analysis in Bogor. The value of $\mathrm{R}^{2}=0.442$, means that $44.2 \%$ of variation models of air temperature in Bogor can be explained by $\mathrm{CO}_{2} \mathrm{e}$ concentration and the rest, $55.8 \%$, is affected by other factors. The modelling of these two stations was in local scale based on the observation data of GHGs concentration in the observed station.

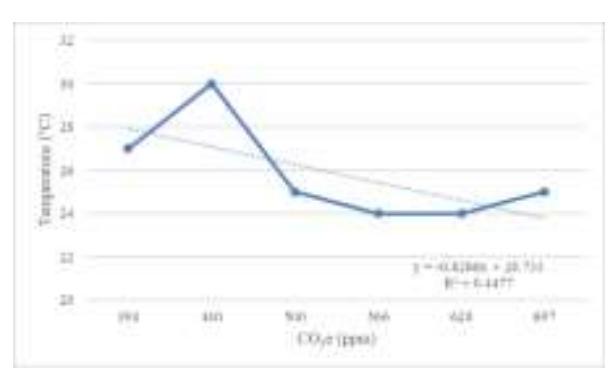

(a)

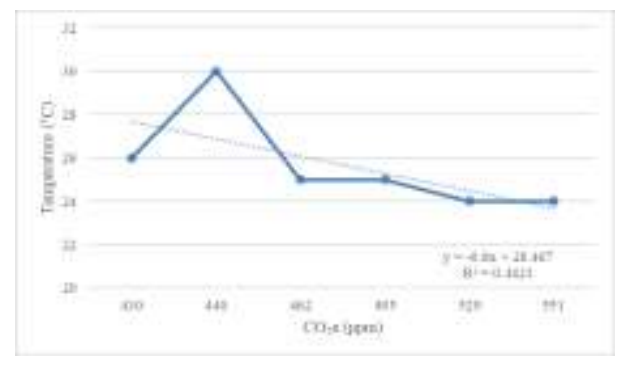

(b)

Fig 4. The relationship between equivalent $\mathrm{CO}_{2}\left(\mathrm{CO}_{2} \mathrm{e}\right)$ and temperature (a) in Serpong; (b) in Bogor.

The increasing greenhouse gases (GHGs) in the atmosphere increases the earth's surface average temperature and could affect global climate change. This research was in line with sustainable development goals (SDGs) Goal 11 on sustainable of cities and communities and Goal 13 on climate change actions. Monitoring air quality indicators including GHGs in urban areas was an effort to support low-carbon city development.

With the characteristics of environment in each location, the values of $\mathrm{CO}_{2}$ and $\mathrm{CH}_{4}$ concentrations in Serpong shows a value higher than in Bogor. Besides, the variation value of GHGs concentration in Serpong is more various than in Bogor. It is in line with previous research which stated that in an urban area, the GHGs concentration is affected by the meteorological condition and its environmental characteristics $[4,5,6]$.

This study shows that relation between air temperature and GHGs concentration has a negative correlation. It is in accordance with the previous research [15] about the negative correlation analysis between $\mathrm{CO}_{2}$ concentration and the global data of temperature for 425 million years. However, this research is contrary to the result of a previous research [5] in which air temperature and $\mathrm{CO}_{2}$ concentration have a positive correlation relation in the rainy season and dry season. Besides, when related with the global data as shown previous research [5] in which a trend of the global temperature rise is in line with the trend of carbon increase, cannot be shown in this research. It is probably caused by the used data which are local measurement data with a short measurement period.

\section{Conclusion}

The concentration of greenhouse gases (GHGs) which keeps rising globally is supposedly caused by the global temperature rise and the phenomenon of climate change. This 
research, partially, uses local data to analyse the effect of GHGs concentration in the level of thermal comfort. However, the relation between the effect of GHGs concentration to the thermal comfort indirectly showed by the relation between GHGs concentration to the air temperature. It was because the GHGs concentration basically affects temperature and the value of temperature itself with RH becomes the indicator of thermal comfort. The GHGs concentration which supposedly affects the temperature which is a trend of the GHGs increase will be in line with a trend of temperature rise. However, in this case, the research shows a negative correlation value. It might be caused by other factors, such as solar radiation, land cover, vegetation, and so on, were stronger than GHGs concentration in affecting the value of ambient air temperature. This research needs a further analysis of other factors which probably affect thermal comfort.

\section{References}

1. M. Roth, Urban heat island: Handbook of environmental fluid dynamic vol. 2 (CRC Press/Taylor and Francis Group, LLC., 2013)

2. K.M. Parris, Ecology of urban environment (John Wiley \& Sons Ltd., Oxford, 2016)

3. W. Cunningham, M. Cunningham, Environmental science: A global concern (McGraw-Hill Education, New York, 2012)

4. H.T. Nguyen, K-H Kim, C-J Ma, S-J Cho, J.R. Sohn. Env. Research 110, 396-409 (2010)

5. I. Haiduc, M.S. Beldean-Galea. Variation of greenhouse gases in urban areas-case study: $\mathrm{CO}_{2}, \mathrm{CO}$ and $\mathrm{CH}_{4}$ in three Romanian Cities. Air quality-models and applications, ed Popovic D (InTech, ResearchGate, 2011)

6. S. Sahay, C. Ghosh, Environ. Monit. Assess. 185, 123-142 (2013)

7. T. Honjo, Global Environmental Research 13, 43-47 (2009)

8. A.E. Croitoru, R.H. Batinas, and L. Muresan. Analysis of NOx air quality indicators in urban areas of Cluj County, Romania (International Multidisciplinary Scientific Geoconference (SGEM), Albena, 2014)

9. K. Pantavou, A. Mavrakis, Geofizika 32 (2015)

10. J.A. Orosa, A.M. Costa, A.R. Fernandez, G. Roshan, Journal of Environmental Health Science and Engineering 12, 46 (2014)

11. I. Charalampopoulos, I. Tsiros, A. Chronopoulou-Sereli, A. Matzarakis, Urban Ecosyst. 16, 217-233 (2013)

12. K. Saifullah, B. Barus, E. Rustiadi, IOP Conference Series: Earth and Environmental Science 54 (2017)

13. S. Setiawati, H. Alikodra, B. Pramudya, A.H. Dharmawan, Sosiohumaniora 17, 2, 178$187(2015)$

14. CCOHS (Canadian Centre for Occupational Health and Safety). Humidex Rating and Works http://www.ccohs.ca/oshanswers/phys_agents/humidex.html access on December 25, 201608.15 (2016)

15. W. Davis, Climate 5, 76, 1-35 (2017) 